\title{
UPAYA PENGUATAN PEMAHAMAN MENULIS DESKRIPSI DAN NARASI PADA PENULISAN BUKU LAPORAN HASIL BELAJAR SISWA PAUD DI DEPOK
}

\author{
Fajar Kurniadi, Hilda Hilaliyah, Nicky Rosadi \\ Universitas Indraprasta PGRI Jakarta
}

\begin{abstract}
Abstrak
Tujuan penulisan laporan kegiatan ini adalah untuk mengetahui efektivitas kegiatan yang dilakukan guna menyegarkan pemahaman guru pada saat menulis laporan hasil belajar. Laporan belajar siswa adalah hal yang ditunggu para orangtua untuk melihat sejauh mana perkembangan anaknya di lingkungan sekolah. Buku laporan hasil belajar merupakan media penyampai segala perkembangan dan prestasi siswa kepada orangtuanya. Oleh karena itu, isi dalam buku ini harus dapat mewakili perkembangan anak di dunia nyata. Adapun metode yang digunakan dalam kegiatan ini adalah dengan melakukan penyuluhan dan pendampingan serta mendengarkan secara langsung masalah yang dihadapi para guru. Diharapkan, dengan melakukan kegiatan ini, pengetahuan para guru mengenai penulisan narasi dan deskripsi menjadi lebih segar dan terbarukan. Hasil dari kegiatan ini adalah penyegaran pola tulis naratif dan deksriptif yang diterapkan pada kegiatan siswa dengan lebih efektif.
\end{abstract}

Kata Kunci: Narasi, Deskripsi, Buku Laporan

\section{PENDAHULUAN}

Pendidikan anak usia dini dimulai dari lingkungan keluarga dan berlanjut di lingkungan sekolah dan masyarakat. Keluarga memiliki andil yang besar dalam peletakkan dasar pendidikan bagi anak, seperti pendidikan agama, moral, sopan dan santun, dan tahap pengembangan adaptasi anak untuk masuk ke lingkungan selanjutnya. Di sekolah, anak usia dini belajar bersosialisasi dengan teman sebayanya. Pada tahap pembelajaran sosialisasi ini, guru menyisipkan materi pembelajaran yang sesungguhnya. Konsep bermain masih dipertahankan agar siswa tidak takut atau bosan dengan pembelajaran yang diselenggarakan di sekolah. Di lingkungan masyarakat, anak usia dini masih gemar bermain dan melakukan interasi dengan teman yang berbeda.
Berbagai dinamika yang ada dalam pembelajaran anak usia dini. Di antaranya berkaitan dengan perancangan dan metode pembelajaran yang diberikan harus sesuai dengan usia dan kearifan lokal sang anak. Hal ini membutuhkan analisis tajam dari para pendidik. Praktis, para pendidik harus mengetahui beberapa hal, seperti latar belakang pendidikan orangtua, latar belakang ekonomi orangtua, agama orangtua, gaya bahasa orangtua, dan pemahaman orangtua akan kosakata sulit. Sangat disayangkan, jika laporan belajar yang ditulis dengan sistematis dan bahasa yang baik, tidak dipahami orangtua karena pendidikannya kurang mampu mencerna diksi yang digunakan.

Beberapa masalah ditemui saat para guru membuat laporan hasil belajar anak usia dini, diantaranya format buku laporan hasil belajar yang tidak dapat 
memuat banyak tulisan, waktu yang sedikit, komponen penilaian yang banyak, dan kearifan lokal. Pertama, format buku laporan yang sudah dibakukan membuat kurang luwesnya para guru untuk mengekspresikan kemampuan siswa dengan sebenarbenarnya. Munculah masalah baru, yakni pengefektifan kata dan pola penggunaan diksi yang harus tepat. (Suparno \& Yunus, 2011) mengemukakan bahwa menulis merupakan suatu kegiatan penyampaian pesan (komunikasi) dengan menggunakan bahasa tulis sebagai alat atau medianya. Kedua, waktu yang sedikit. Waktu kadang menjadi musuh utama para guru dalam proses penulisan laporan hasil belajar. Jika ingin mengikuti jadwal yang diberikan, terkadang, hanya diberikan waktu 3-5 hari untuk menulis buku laporan hasil belajar. Ditambah lagi, dinamika perkembangan siswa yang banyak membuat proses pemilihan kata menjadi lebih panjang. Ketiga, kearifan lokal. beragamnya latar belakang agama, budaya, bahasa, ekonomi, dan pendidikan orangtua dan lingkungan sekitar dapat menjadi masalah bagi para guru dalam menulis rapot. Di tengah masalah yang dihadapinya, guru harus tetap menulis laporan belajar yang akurat.

Laporan belajar yang akurat akan menaikkan kualitas belajar di sekolah tersebut. Hal ini pun disampaikan oleh (Mardapi, 2003) menyatakan "Usaha peningkatan kualitas pendidikan dapat ditempuh melalui peningkatan kualitas pembelajaran dan kualitas sistem penilaian. Keduanya saling terkait, sistem pembelajaran yang baik akan menghasilkan kualitas belajar yang baik. Selanjutnya sistem penilaian yang baik akan mendorong guru untuk menentukan strategi mengajar yang baik dan memotivasi siswa untuk belajar yang lebih baik." Mutu pendidikan adalah tujuan utama diadakannya pembelajaran. Pembelajaran yang baik dimulai dengan perencanaan yang matang dan pengevaluasian yang andal, pun demikian pada proses penulisannya. Kesalahan pemakaian kata-kata akan menimbulkan makna yang berbeda. Hal ini akan menghambat keberterimaan makna dari penulis kepada pembaca (orangtua).

Laporan belajar anak usia dini tidaklah samadengan laporan belajar siswa SD hingga SMA. Laporan belajar anak usia dini didominasi oleh tulisan berisi penceritaan kemampuan dan perkembangan di sekolah. Jenis tulisan yang digunakan biasanya merujuk pada paragraf narasi atau deskripsi. Narasi yang berarti penceritaan, dapat memuat perjalanan kemampuan anak dari yang tidak mampu menjadi mampu. Deskripsi yang bermakna penggambaran, dapat berupa pencitraan kemampuan siswa secara langsung. Melihat kenyataan di atas, kami melakukan sebuah kegiatan pengabdian kepada masyarakat di lingkungan sekolah anak usia dini. Kegiatan ini menitikberatkan pada penyuluhan dan penyegaran kemampuan menulis narasi dan deksripsi bagi para guru. Semoga kegiatan ini tepat guna dan bermanfaat bagi mitra dan para pembaca.

\section{Landasan Teori}

1. Evaluasi Pembelajaran

Evaluasi merupakan tahapan akhir dari proses pembelajaran. Tahapan yang menjadi ujung tombak untuk menyatakan pembelajaran berhasil atau gagal. Tahapan yang harus selaras dengan perencanaan dan metode ini, harus dilakukan secara berkesinambungan. Hal ini harus sejalan dengan prinsip belajar sepanjang hayat, belajar harus dilakukan di mana saja dan kapan saja. Belajar untuk mengubah dari yang tidak mampu menjadi mampu. Hal ini pun diperkuat oleh (Sudjana 
\& Ibrahim, 2004) yang mengatakan bahwa "Perubahan sebagai hasil proses belajar dapat ditunjukkan dalam berbagai bentuk seperti berubah pengetahuannya, kecakapan dan kemampuannya, daya reaksinya, daya penerimaannya dan lain-lain aspek yang ada pada individu." Diharapkan, dengan pembelajaran, individu dapat berubah pengetahuannya, kecakapannya, dan kemampuannya. Hal yang paling dasar adalah mengubah pengetahuan. Setelah pembelajar mendapatkan informasi dari ilmu yang diberikan oleh guru, informasi itu akan disimpan sebagai pengetahuan dan diaplikasikan dalam kehidupan. Semakin sering dan banyak diaplikasikan, pembelajar akan menjadi mampu. Mampu menguasai terbiasa melakukannya sehingga ia akan menjadi cakap. Semakin sering dan banyak pengaplikasian kemampuan yang didapat tadi, maka pembelajar akan menjadi cakap. Cakap yang dimaksud adalah pandai atau mahir. Untuk dapat masuk ke level cakap, pembelajar harus dapat konsisten dan kontinu dengan mengajarkan ilmunya itu kepada orang lain.

(Arifin, 2012) Dalam sistem pembelajaran (maksudnya pembelajaran sebagai suatu sistem), evaluasi merupakan salah komponen penting dan tahap yang harus ditempuh oleh guru untuk mengetahui keefektifan pembelajaran.

Evaluasi yang dilakukan oleh para guru anak usia dini dilaporkan melalui buku laporan hasil belajar yang berisi cerita dan penggambaran perkembangan sang anak selama di sekolah. Hal ini tentu membuat keberadaan buku laporan hasil belajar menjadi vital, apa lagi isi di dalamnya, yakni narasi dan deskripsi.

2. Narasi

Menurut (Keraf, 2010), narasi adalah suatu bentuk wacana yang berusaha menggambarkan dengan sejelas-jelasnya kepada pembaca suatu peristiwa yang telah terjadi. Dengan kata lain, narasi berusaha menjawab sebuah pertanyaan "apa yang telah terjadi”. Bentuk karangan ini berusaha mengisahkan suatu kejadian atau peristiwa yang seolaholah pembaca dapat melihat dan dapat mengalami peristiwa itu. Unsur yang penting dalam narasi ini adalah perbuatan atau tindakan dan rangkaian waktu peristiwa itu terjadi. Hal ini senada dengan (Purwaningrum \& Purwadi, 2013) yang menyatakan "Melalui tulisannya, pengarang ingin meyakinkan pembaca atau pendengar dengan jalan menceritakan apa yang ia lihat dan ketahui.

(Sirait, 1985) mengemukakan bahwa "Narasi adalah karangan yang berkenaan dengan rangkaian peristiwa. Tujuan dari narasi ini mengatakan kepada pembaca tentang apa-apa yang terjadi." Dengan demikian, pokok permasalahan dalam narasi adalah perbuatan, tindakan, atau aksi.

Berdasarkan pengertianpengertian narasi di atas, dapat disimpulkan bahwa narasi adalah karangan maupun cerita yang menyajikan suatu peristiwa atau kejadian serta bagaimana peristiwa itu berlangsung berdasarkan urutan waktu. Di dalam paragraf narasi terdapat tokoh, latar, alur, karakter tokoh, tema, sudut pandang, dan amanat. Paragraf narasi merupakan bagian dari sebuah cerita atau kisah. Dengan kata lain, sebuah cerita tidak 
hanya menggunakan paragraf narasi, tapi juga dapat terdiri atas jenis paragraf lainnya.

3. Karakteristik Narasi

Berdasarkan definisi di atas, narasi mempunyai karakteristik sebagai berikut

a. Karangan narasi menyajikan suatu peristiwa atau kejadian yang berdasarkan pada urutan waktu.

b. Karangan narasi memuat tokoh, latar, alur, karakter tokoh, tema, sudut pandang, dan amanat.

c. Karangan narasi merupakan bagian dari sebuah cerita atau kisah. Dengan kata lain, sebuah cerita tidak hanya menggunakan paragraf narasi, tapi juga dapat terdiri atas jenis paragraf lainnya.

4. Ciri Narasi

a. Alur

Alur dan jalan cerita tidak dapat dipisahkan, tetapi harus dibedakan. Orang sering mengacaukan kedua pengertian tersebut. Jalan cerita memuat kejadian. Akan tetapi suatu kejadian terjadi karena ada sebabnya, ada alasannya. Sesuatu yang menggerakkan cerita tersebut dinamakan alur, yaitu segi rohaniah dari suatu kejadian. Suatu kejadian berkembang jika ada yang menyebabkan terjadinya perkembangan, dalam hal ini konflik. Penerapannya pada proses penulisan laporan akhir adalah, guru dapat menceritakan kemampuan awal siswa hingga ia berhasil meraih prestasi. Prestasi itu dianalogikan menjadi masalah dalam alur di atas. b. Penokohan

Salah satu ciri narasi adalah mengisahkan tokoh cerita bergerak dalam sutu rangkaian perbuatan atau mengisahkan tokoh cerita terlibat dalam suatu peristiwa atau kejadian. Tindakan, peristiwa, kejadian itu disusun bersama-sama sehingga mendapatkan kesan atau efek tunggal. Untuk mendapatkan pemusatan kesan itu, perlu diadakan pemilihan dan pembatasan tokoh yang akan bertindak atau yang akan mengalami peristiwa atau kejadian dalam keseluruhan narasi. Guru harus dapat memahami karakteristik siswa dengan baik dan menjadikannya menjadi tokoh utama di buku laporan hasil belajar.

5. Latar

Penyebutan nama latar secara pasti atau secara umum dalam narasi sebenarnya menyangkut esensi dan tujuan yang hendak dicapai narasi itu sendiri. Narasi informasional esensinya adalah hasil pengamatan pengarang yang diinformasikan kepada pembaca. Untuk itu kesatuan kesan dapat diperoleh dengan pembatasan penyebutan latar, dengan konsekuensi adanya pembatasan peristiwa atau perbuatan yang dialami tokoh. Narasi artistik esensinya adalah hasil imajinasi pengarang untuk memberikan pengalaman estetik kepada pembaca. Penyebutan latar secara konsisten, berfungsi merangsang imajinasi pembaca untuk menghasilkan suatu dunia mandiri yang utuh. Dunia mandiri yang utuh dalam narasi artistik tampak dengan adanya konsistensi antara pengisahan latar fisik dengan suasana psikologis yang dibangkitkan. 
6. Deskripsi

Menurut (Keraf, Eksposisi dan Deskripsi, 1982), deskripsi atau pemerian merupakan sebuah bentuk tulisan yang bertalian dengan usaha para penulis untuk memberikan perincian-perincian dari objek yang dibicarakan. (Rusyana, 1984) mengemukakan bahwa deskripsi, lukisan, atau pemerian ialah karangan yang melukiskan sesuatu, menyatakan apa yang diindera, melukiskan perasaan dan perilaku jiwa dalam wujud kalimat.

Masih menurut (Rusyana, 1984), terdapat kaitan antara jenis karangan yang satu dengan jenis karangan yang lainnya termasuk antara deskripsi, dengan narasi, eksposisi dan argumentasi. Deskripsi merupakan jenis karangan yang cenderung dipergunakan oleh ketiga jenis karangan lainnya sebagai alat untuk mengonkretkan pokok pembahasan.

Sedangkan menurut (Widarso, 2000) berpendapat bahwa deskripsi adalah tulisan atau karangan yang menggambarkan, yang digambarkan dapat saja suatu benda, orang (atau masyarakat), tempat, atau suatu suasana pada saat tertentu.

Berdasarkan pendapat para ahli di atas, dapat dikatakan bahwa deskripsi adalah jenis paragraf yang menggambarkan sesuatu dengan jelas dan terperinci. Dalam karangan deskripsi, dikemukakan hal-hal yang menyentuh pancaindera, baik penglihatan, pendengaran, penciuman, pengecap, maupun indera peraba. Penggambaran atau pelukisan dalam deskripsi berupa rincian yang tersusun berurutan, mungkin dari kanan ke kiri, dari depan ke belakang, dan sebagainya. Jenis karangan ini dapat digunakan untuk menggambarkan benda atau manusia dengan mengamati secara detail atau rinci mengenai bentuk, warna, keadaan obyek, menurut penangkapan alat indera penulis. Oleh sebab itu, dalam prosesnya, unsur perasaan lebih tajam daripada pikiran.

\section{METODE PELAKSANAAN}

Pelaksanaan pengabdian ini
dilakukan dengan melakukan penyuluhan. Penyuluhan yang dilakukan dengan membangkitkan ingatan kembali mengenai materi narasi dan deskripsi. Setelah ingatan para guru bangkit, langkah selanjutnya adalah memaksimalkan potensi dan kreativitas menyaji cerita dengan bahasa dan ciri khas yang dimiliki. Di sela penyuluhan, beberapa guru melakukan diskusi dan mengamati dengan saksama materi yang diberikan. Setelah penyuluhan selesai, kegiatan selanjutnya adalah dengan melakukan tanya-jawab dan uji coba keberterimaan materi.

Kegiatan pengabdian kepada masyarakat ini dilakukan di TK Aku Anak Indonesia yang beralamat di Jalan Pinang II Kecamatan Limo Kota Depok Jawa Barat Indonesia.

\section{HASIL DAN PEMBAHASAN}

Hasil dari kegiatan ini adalah menyegarkan ingatan dan kemampuan menulis narasi dan deskripsi anak usia dini. Para guru diminta mengembangkan kalimat dari kata yang umum dengan pengembangan narasi dan deskripsi. Proses pengembangannya masih berupa pelisanan langsung. Dalam obrolan santai, mereka memberikan beberapa contoh kata, ceria contohnya. Seorang anak dinyatakan ceria harus memenuhi beberapa kriteria yakni, senyuman, gerakan tubuh, ekspresi wajah. Untuk dapat menilai anak usia dini sebagai anak 
yang ceria, guru harus dapat mengidentifikasi keberadaan anak dari awal hingga akhir sekolah. Apakah ada sedikit aktivitas yang menggangu keceriaan sang anak, atau apakah ada masalah di sekolah yang melibatkan sang anak seperti menangis, mengompol, menumpahkan makanan atau minuman, berteriak, dan lainnya. Setelah melakukan identifikasi secara matang, guru harus dapat menuliskan kejadian-kejadian itu dalam buku harian sang anak. Buku itulah yang menjadi catatan penting dan harus dapat menjadi bahan pertimbangan pembuatan dan penulisan laporan hasil belajar siswa. Sebelum menulisnya, guru harus meramu kosakata agar penafsiran orangtua tidak berbeda dengan yang dimaksud. Guru pun harus mengambil sudut pandang sebagai orangtua anak, di mana setiap anak mempunyai latar belakang orangtua yang berbeda. Guru harus memahaminya dan memilih diksi yang tepat. Kesulitan yang sering dialami adalah saat memilih kata untuk orangtua siswa dengan pendidikan atau tingkat ekonomi yang rendah. Diksi yang digunakan haruslah diksi yang lugas dan tidak berbelit, sebagai contoh, "Ananda $\mathrm{X}$ telah berhasil mewarnai gambar tanpa melewati garis."

Selanjutnya adalah tahap implementasi. Berhubung sekolah dalam keadaan libur dan guru sedang tidak menulis buku laporan hasil belajar, maka tahapan implementasi akan ditunda hingga agenda sekolah melakukan evaluasi dan menulis hasilnya. Biasanya, hal ini dilakukan pada bulan Desember atau April.

\section{SIMPULAN}

Berdasarkan hasil yang didapat dari kegiatan ini, maka dapat disimpulkan:
1. Pentingnya penguasaan kemampuan menulis narasi dan deskripsi di kalangan guru PAUD.

2. Aspek pemilihan diksi harus diperkuat dalam proses penulisan narasi di buku laporan hasil belajar.

3. Perlu dilakukan pendampingan kembali proses penulisan narasi dan pemilihan diksi di waktu mendatang.

\section{DAFTAR PUSTAKA}

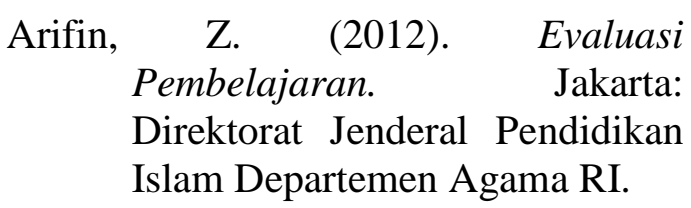

Keraf, G. (1982). Eksposisi dan Deskripsi. Ende: Nusa Indah.

Keraf, G. (2010). Argumentasi dan Narasi. Jakarta: Gramedia.

Mardapi, D. (2003). Desain dan penilaian pembelajaran mahasiswa. Lokakarya Sistem Jaminan Mutu Proses Pembelajaran. Yogyakarta: Universita Gadjah Mada.

Purwaningrum, S. W., \& Purwadi, A. (2013). Penggunaan Metode Peta Pikiran (Mind Mapping) Untuk Meningkatkankemampuan Menulis Narasi Siswa Sekolah Menengah Pertama. Basastra, 113.

Rusyana, Y. (1984). Penggunaan Bahasa dan Jenis Karangan dalam Penyusunan Buku Pelajaran Sejarah. Bandung : Diponegoro.

Sirait, B. (1985). Pedoman Karang Mengarang. Jakarta: Pusat Pembinaan dan Pengembangan Bahasa, Departemen Pendidikan dan Kebudayaan. 
Sudjana, N., \& Ibrahim. (2004).

Widarso, W. (2000). Kiat Menulis dalam Penelitian dan Penilaian Bahasa Inggris. Yogyakarta: Pendidikan. Bandung: Sinar Kanisius.

Baru Algesindo.

Suparno, \& Yunus, M. (2011).

Keterampilan Dasar Menulis.

Jakarta: Universitas Terbuka. 